\title{
Characteristics of Fertility Transition Response to the Cumulative Effective Low Temperature in a Two-Line Male Sterile Rice Cultivar
}

Linxuan Wu, Huazhen Rong, Chun Chen, Xin Lin, Jiafeng Wang, Wuming Xiao, Cuihong Huang, Tao Guo, Hui Wang and Ming Huang ${ }^{*}$ (i)

\begin{abstract}
Background: Photo-thermo-sensitive genic male sterile (PTGMS) rice (Oryza sativa L.) is usually considered two-line male sterile rice because of its dual-purpose in two-line hybrid rice system: under short days and low temperatures, it is fertile and used for self-propagation, but under long days and high temperatures, it is sterile and used for hybrid seed production. Therefore, photoperiod and temperature conditions are extremely important for the fertility transition of two-line male sterile rice. In recent years, there have been frequent occurrences of abnormally lowtemperature (ALT) resulting in failure of two-line hybrid rice seed production. The daily average temperature (DAT) during ALT events is sometimes higher than the critical sterility-inducing temperature (CSIT) of two-line male sterile rice, of which the night temperature is lower than the CSIT. DAT has been traditionally used as the single indicator of pollen fertility transition, but it is unknown why the fertility of two-line male sterile rice in seed production restored fertility under ALT conditions.
\end{abstract}

Results: For Hang93S (H93S), a newly released PTGMS line, we hypothesized fertility transition is determined mainly by the cumulative effective low temperature (ELT) and only a certain duration of low temperature is required every day during the fertility-sensitive period. This study simulated ALTs where the DAT was higher than the CSIT while some segments of night temperature were lower than the CSIT. The results showed H93S exhibited a fertility transition to varying degrees. Moreover, fertility was restored under simulated ALT conditions and pollen fertility increased with increasing cumulative ELT, indicating that the fertility transition was affected primarily by the cumulative ELT. Results also indicated that pollen fertility increased as the number of treatment days increased.

Conclusions: The fertility transition is caused mainly by the cumulative ELT. In two-line male sterile rice breeding, the effects of day length, ALT at night, and continuous response days should be considered together. The present study provides new insight into fertility transition so breeders can more effectively utilize the two-line male sterile rice, H93S, in breeding programs.

Keywords: Two-line male sterile rice, Fertility transition, Critical sterile inducing temperature, Effective low temperature

\footnotetext{
* Correspondence: mhuang@scau.edu.cn

National Engineering Research Center of Plant Space Breeding, South

China Agricultural University, Guangzhou 510642, People's Republic of China
}

\section{Springer Open}

(c) The Author(s). 2021 Open Access This article is licensed under a Creative Commons Attribution 4.0 International License, which permits use, sharing, adaptation, distribution and reproduction in any medium or format, as long as you give appropriate credit to the original author(s) and the source, provide a link to the Creative Commons licence, and indicate if changes were made. The images or other third party material in this article are included in the article's Creative Commons licence, unless indicated otherwise in a credit line to the material. If material is not included in the article's Creative Commons licence and your intended use is not permitted by statutory regulation or exceeds the permitted use, you will need to obtain permission directly from the copyright holder. To view a copy of this licence, visit http://creativecommons.org/licenses/by/4.0/. 


\section{Background}

Early investigations of hybrid rice (Oryza sativa L.) cultivars developed via the three line system involving a cytoplasmic male sterile A-line, maintainer B-line and restorer R-line (Yuan and Tang 1999), demonstrated a $10-30 \%$ yield advantage of the hybrid cultivars over conventional rice cultivars which was attributed to heterosis (Virmani et al. 1982). Additional success was achieved by introducing a two-line hybrid rice system (Chen et al. 2011) in which the male parent is fertile under low temperatures and short days but sterile under high temperatures and long days. The discovery of the photoperiodsensitive genic male sterility (PGMS) rice line, NongKen58S, in Hubei, China, revolutionized the use of rice heterosis (Shi 1985; He et al. 2007). PGMS and the more recently developed PTGMS lines are the two major types of male sterile rice lines used in two-line hybrid system (Chen and Xiao 2010; Zhou et al. 2012; Chang et al. 2016). With a better understanding of the photoperiodand temperature-induced fertility transitions associated this system, various genetic models or hypotheses have been proposed for producing two-line male sterile rice, substantially expediting the pace of the breeding process and the development of hybrid combinations (Zhou et al. 2014; Arasakesary et al. 2015; Wu et al. 2016; Barman et al. 2019; Chen et al. 2020). The planting area of two-line hybrid rice is continually increasing and has gradually approached that of three-line hybrid rice, thus playing an increasingly important role in ensuring food security in China (Yuan 2014). Nonetheless, the two-line system has inherent problems associated with the hybrid seed production process, with fertility being affected by the photoperiod/thermo- conditions (Chen et al. 2011). The fertility of two-line male sterile rice can be restored under low temperatures and short day length, resulting in self-propagation, while high temperatures with long days maintain male sterility and can be used for hybrid seed production (Ding et al. 2012; Zhou et al. 2012; Chang et al. 2016; Wang and Deng 2018). However, owing to this unique fertility transition relationship, specialized breeding procedures are required, including the use of artificial climate chambers, the proper timing of planting, and the selection of suitable locations (DeGuzman and Oard 2019). As such breeding and seed production have been limited, thus hindering further development of two-line hybrid rice. During the breeding process of PTGMS rice lines, the CSIT drifts upward (e.g. the CSIT increased $0.9^{\circ} \mathrm{C}$ for PeiAi64S, and $2.0{ }^{\circ} \mathrm{C}$ for Hengnong S-1) after 3 to 4 generations of propagation (Lei et al. 2014). It was proposed that heterozygosity for the minor male sterility-related gene(s) may cause CSIT drift in two-line male sterile rice. Thus, for twoline hybrid seed production, it is necessary to fully consider the photoperiod and temperature to evaluate the fertility of female parents when determining the location and period for hybrid seed production (Chen et al. 2011; Lei et al. 2014).

In recent years, abnormal-low temperature weather events have been frequent, causing the failure of twoline hybrid rice seed production (Lei and Chen 2015). ALT refers to the DAT being higher than the CSIT, and some segments of the nighttime temperature being lower than the CSIT. For instance, Wan'ning $\left(110.29^{\circ} \mathrm{N}\right.$, $\left.18.84^{\circ} \mathrm{E}\right)$, which located north of Lingshui $\left(109.95^{\circ} \mathrm{N}\right.$, $18.57^{\circ} \mathrm{E}$ ), is generally considered an area that is not suitable for two-line sterile line propagation. However, we observed successive propagation of two-line male sterile rice in the Dongxing Farm Station of Wan'ning for seven consecutive years primarily due to the shift of the sensitive period to occur around mid-February, during which the nighttime low temperatures range from $20.0^{\circ} \mathrm{C}$ to $23.0^{\circ} \mathrm{C}$ and the daytime temperatures range from $25.0^{\circ} \mathrm{C}$ to $28.0^{\circ} \mathrm{C}$, according to historical weather data from 2012 to 2018. According to our field measurements, this region occasionally experienced daytime temperatures ranging from $29.0^{\circ} \mathrm{C}$ to $30.0^{\circ} \mathrm{C}$, and the DAT ranged from $21.0^{\circ} \mathrm{C}$ to $24.0^{\circ} \mathrm{C}$.

These variations in temperature represent the primary bottleneck limiting reliable hybrid seed production via a two-line male sterile rice system (Chen and Xiao 2010). Chen et al. (2011) proposed that the thermo-sensitive dual-purpose genic male sterile rice must be exposed to a certain amount of cumulative low temperature to change the fertility. However, the mechanism through which low temperature exposure affecting the fertility transition of sterile lines has not been elucidated. Further, according to our observations for the past several years, the DAT of ALT events was sometimes higher than the CSIT of two-line male sterile rice, which fails to explain why the fertility was restored for the sterile line during the hybrid seed production. Thus, we hypothesized that the fertility transition of the two-line male sterile rice during the fertility-sensitive period is determined mainly by the cumulative effective low temperature (ELT) and that only a certain cumulative of low temperature exposure is needed every day during the fertility-sensitive period during the stage IV to VI of the young panicle differentiation (Chen et al. 2011). When a certain cumulative ELT is reached, the sterile line transitions to a fertility line. In the present study, we used the PTGMS lines H93S and PeiAi64S (PA64S) to investigate the photo-thermo-response characteristics and the correlation between the number of effective treatment days for fertility transition and the cumulative ELT $\left(\Sigma \mathrm{T}_{\Delta}\right)$. The objectives of this study were to: 1$)$ validate our hypothesis that the fertility transition is determined mainly by the cumulative ELT and a certain duration of low temperature exposure is needed every 
day during the fertility-sensitive period, and 2) characterize and explore the regulation of ELT during the fertility transition in two-line male sterile rice.

\section{Materials and Methods Plant Materials}

H93S, a newly released PTGMS line developed at South China Agricultural University, was derived from the crossing S-25 (a male sterile breeding line derived from C815S/Hefengzhan as the recurrent parent) and M-93 (an inbred line with large panicles and good grain quality selected from the space-radiation-induced mutagenesis of Texianzhan13), followed by backcrossing and selfing (Huang et al. 2018). Further, PA64S, which was used as a control, is also a PTGMS line and has been the most successful female line with the greatest planting area among early two-line hybrid rice in China $(\mathrm{Hu}$ et al. 2015).

\section{Planting, Transplanting and Sampling}

H93S and PA64S were sown every $10 \mathrm{~d}$ from March 13 through June 11, 2019, for a total of 10 sowing cycles. For each sowing, at least 100 seedlings (30-d old) spaced $12.5 \mathrm{~cm} \times 25 \mathrm{~cm}$ were transplanted into fields at the South China Agricultural University Experimental Station, Guangzhou, China $\left(23.13^{\circ} \mathrm{N}, 113.36^{\circ} \mathrm{E}\right)$. Plants whose distance between the ligule of the flag leaf and that of the next leaf on the main-culm was about $2.0 \mathrm{~cm}$, were transplanted into the plastic buckets (each bucket carrying three plants was used per treatment, and each treatment was replicated three times) for use in the treatments. At the end of the treatment, the tillers whose distance between the ligule of flag leaf and that of the next leaf on the culm was about $1.0 \mathrm{~cm}$ (Chen et al. 2011) were marked, after which the plants were moved back to the field for normal growth under natural conditions (Zhang et al. 2011; Bai et al. 2015).

\section{Determination of the CSIT}

The temperature and daily photoperiod were selected according to the Ministry of Agriculture Standard of China (NY/T1215-2006) (Sun et al. 2006) with slight modifications (for photoperiods of $11.5 \mathrm{~h}$ and $12.5 \mathrm{~h}$, the treatment $23.0^{\circ} \mathrm{C}$ was applied via an artificial climate chamber; for photoperiods of $13.5 \mathrm{~h}$ and $14.5 \mathrm{~h}$, treatments involved $22.5^{\circ} \mathrm{C}$ ); additional details are provided in Table 1. The temperature was constant, and the light intensity was 30,000 $\mathrm{Lx}$ during the day and $0 \mathrm{Lx}$ at night.

\section{Effects of the ELT}

$\mathrm{Xu}$ et al. (2002) released a protocol of photo-treatment and thermo-treatment settings to simulate low temperature conditions. The temperature settings were as follows: $05: 00-11: 00$ at $25.0^{\circ} \mathrm{C}, 11: 00-17: 00$ at $26.0^{\circ} \mathrm{C}, 17: 00-23: 00$ at $23.5^{\circ} \mathrm{C}$, and $23: 00-05: 00$ (the next day) at $19.5^{\circ} \mathrm{C}$, with an average of $23.5^{\circ} \mathrm{C}$ during the day. The light intensity settings were as follows: 06: 30-08:00 at 5000 Lx, 08:00-18:00 at 20,000 Lx, 18:0020:00 at $5000 \mathrm{Lx}$, and 20:00-06:00 at $0 \mathrm{Lx}$. On the basis

Table 1 Fertility results in response to light-temperature combinations for the CSITs of H93S and PA64S

\begin{tabular}{|c|c|c|c|c|c|}
\hline \multirow{2}{*}{$\begin{array}{l}\text { Daily } \\
\text { photoperiod } \\
\text { time (h) }\end{array}$} & \multirow{2}{*}{$\begin{array}{l}\text { Temperature } \\
\left({ }^{\circ} \mathrm{C}\right)\end{array}$} & \multicolumn{2}{|l|}{ H93S } & \multicolumn{2}{|l|}{ PA64S } \\
\hline & & PFP (\%) & SSP (\%) & PFP (\%) & SSP (\%) \\
\hline \multirow[t]{3}{*}{11.5} & 28.0 & 0 & 0 & 0 & 0 \\
\hline & 24.0 & $0.01 \pm 0$ & 0 & $78.31 \pm 5.27$ & $39.54 \pm 7.32$ \\
\hline & 23.0 & $50.51 \pm 5.53$ & $17.84 \pm 4.08$ & $60.37 \pm 4.86$ & $22.42 \pm 2.94$ \\
\hline \multirow[t]{3}{*}{12.5} & 28.0 & 0 & 0 & 0 & 0 \\
\hline & 24.0 & 0 & 0 & $0.34 \pm 0.29$ & 0 \\
\hline & 23.0 & $8.21 \pm 1.81$ & $2.54 \pm 0.92$ & $25.25 \pm 4.61$ & $15.89 \pm 0.22$ \\
\hline \multirow[t]{4}{*}{13.5} & 28.0 & 0 & 0 & 0 & 0 \\
\hline & 24.0 & 0 & 0 & 0 & 0 \\
\hline & 23.0 & 0 & 0 & $1.19 \pm 0.49$ & $0.24 \pm 0.22$ \\
\hline & 22.5 & $27.27 \pm 2.47$ & $12.22 \pm 2.84$ & $31.89 \pm 10.46$ & $16.93 \pm 3.89$ \\
\hline \multirow[t]{4}{*}{14.5} & 28.0 & 0 & 0 & 0 & 0 \\
\hline & 24.0 & 0 & 0 & 0 & 0 \\
\hline & 23.0 & 0 & 0 & 0 & 0 \\
\hline & 22.5 & $8.91 \pm 3.55$ & $3.72 \pm 1.40$ & $16.94 \pm 4.11$ & $9.85 \pm 1.39$ \\
\hline
\end{tabular}

The temperature and daily photoperiod were selected according to the Ministry of Agriculture Standard of China (NY/T1215-2006), with modifications. (The modifications included the following additional treatments: an $11.5 \mathrm{~h}$ photoperiod at $23.0^{\circ} \mathrm{C}$, a $12.5 \mathrm{~h}$ photoperiod at $22.5^{\circ} \mathrm{C}$, a $13.5 \mathrm{~h}$ photoperiod at $22.5^{\circ} \mathrm{C}$, and a $14.5 \mathrm{~h}$ photoperiod at $22.5^{\circ} \mathrm{C}$.) Abbreviations are: PFP: pollen fertility percentage; SSP: self-seed setting percentage. All data are expressed as the means \pm the standard errors 
of the above settings, the low temperature varied for different durations as outlined in Table 2. The light intensity settings (simulating sunlight) and temperature settings were not synchronized and were mutually exclusive. As shown in Table 2, the temperature was set above the CSIT $\left(T_{c}\right)$ for $t_{1}$ and below $T_{c}$ for $t_{2}$ to simulate ALT (especially low temperatures at night) during the sensitive period, and $\mathrm{T}_{\Delta}$ is the value of the ELT, i.e., the difference between actual treatment temperature $(\mathrm{T})$ and the $\mathrm{T}_{\mathrm{c}} \cdot \mathrm{T}_{\Delta}$ was set to two different values: $\mathrm{T}_{\Delta 1}=$ $2.5^{\circ} \mathrm{C}$ (Supplementary Table S1) and $\mathrm{T}_{\Delta 2}=2.0^{\circ} \mathrm{C}$ (Supplementary Table S2). $\mathrm{T}_{2}$ varied from $7 \mathrm{~h}$ to $17 \mathrm{~h}\left(\mathrm{t}_{2}=7\right.$ $\mathrm{h}, 9 \mathrm{~h}, 11 \mathrm{~h}, 13 \mathrm{~h}, 15 \mathrm{~h}$ and $17 \mathrm{~h}$ ), and together with the different selected $T_{\Delta}, t_{1}$, and $t_{2}$ values, 12 treatments were established in which $t_{1}=24 h-t_{2}-6 h$. For example, assuming that the CSIT of $\mathrm{H} 93 \mathrm{~S}$ is $23.0^{\circ} \mathrm{C}$ (i.e., $\mathrm{T}_{\mathrm{c}}=$ $23.0^{\circ} \mathrm{C}$ ) and that the $\mathrm{T}_{\Delta 1}=2.5^{\circ} \mathrm{C}, \mathrm{t}_{1}=11 \mathrm{~h}$, and $\mathrm{t}_{2}=7 \mathrm{~h}$, the DAT $\left(24.15^{\circ} \mathrm{C}\right.$, Supplementary Table S1) can be calculated. The two-line male sterile rice during the fertility-sensitive period showed different degrees of sensitivity to the $\Sigma \mathrm{T}_{\Delta}$, which relates to our hypothesis concerning the effect of cumulative ELT. The $\Sigma \mathrm{T}_{\Delta}$ can be calculated via $\sum_{1}^{d} T_{\Delta}$, where $d$ is the number of treatment days. The images in Supplementary Fig. S1 show the treatments and facilities used for these studies.

\section{Study of the Response to ELT Treatment Days}

The $\mathrm{T}_{\Delta}$ included six different levels $\left(0^{\circ} \mathrm{C}, 1.0^{\circ} \mathrm{C}, 1.5^{\circ} \mathrm{C}\right.$, $2.0^{\circ} \mathrm{C}, 2.5^{\circ} \mathrm{C}$, and $3.0^{\circ} \mathrm{C}$ ), and at each temperature level, the plants were treated for $4 \mathrm{~d}, 5 \mathrm{~d}, 6 \mathrm{~d}$, and $7 \mathrm{~d}$, resulting in 24 treatments (Supplementary Table S3 and Fig. S1). The treatments included natural light with an actual photoperiod of approximately $13.5 \mathrm{~h}$. At $4 \mathrm{~d}, 5 \mathrm{~d}, 6 \mathrm{~d}$, and $7 \mathrm{~d}$ after treatment, the treated plants in each treatment group were transplanted back to the field.

Table 2 The temperature and light conditions for the $\Sigma T_{\Delta}$ for each day

\begin{tabular}{llll}
\hline \multicolumn{2}{l}{ Temperature conditions } & \multicolumn{2}{l}{ Light conditions } \\
\hline Treatment time $(\mathrm{h})$ & ${\text { Temperature }\left({ }^{\circ} \mathrm{C}\right)}$ & Time range & Light intensity $(\mathrm{Lx})$ \\
6: $(05: 00-11: 00)$ & $25.0^{\circ} \mathrm{C}$ & $06: 30-08: 00$ & 5000 \\
$\mathrm{t}_{1}: 11: 00-\left(11: 00+\mathrm{t}_{1}\right)$ & $26.0^{\circ} \mathrm{C}$ & $08: 00-18: 00$ & 20,000 \\
$\mathrm{t}_{2}:\left(11: 00+\mathrm{t}_{1}\right)-05: 00$ & $\mathrm{~T}_{\mathrm{C}^{-} \mathrm{T}_{\Delta}}$ & $18: 00-20: 00$ & 5000 \\
& & $20: 00-06: 00$ & 0
\end{tabular}

$\mathrm{T}_{\mathrm{c}}$ is the value of the CSIT, the $\mathrm{T}_{\mathrm{c}}$ for $\mathrm{H} 93 \mathrm{~S}$ is $23.0^{\circ} \mathrm{C}$ and for PA64S is $24.0^{\circ} \mathrm{C}$; $\mathrm{T}_{\Delta}$ is the value of the ELT (i.e., the difference between actual treatment temperature $\mathrm{T}$ and $\mathrm{T}_{\mathrm{c}}$ ), the $\mathrm{T}_{\Delta}$ is set at two levels: $\mathrm{T}_{\Delta 1}=2.5^{\circ} \mathrm{C}$ and $\mathrm{T}_{\Delta 2}=2.0^{\circ} \mathrm{C}$; $t_{1}$ and $t_{2}$ are the times at which temperatures above and below the CSIT, respectively, and $t_{2}$ values of $7 h, 9 h, 11 h, 13 h, 15 h$ and $17 \mathrm{~h}$ correspond to $t_{1}$ values $11 \mathrm{~h}, 9 \mathrm{~h}, 7 \mathrm{~h}, 5 \mathrm{~h}, 3 \mathrm{~h}$ and $1 \mathrm{~h}$, respectively, for a total of $18 \mathrm{~h}\left(\mathrm{t}_{1}+\right.$ $t_{2}+6=24 h$ ); The photoperiod settings (simulating sunlight) and temperature settings were not synchronized and were mutually exclusive. Supplementary Table S1 and S2 show the detailed settings

\section{Detection of Pollen Fertility and Self-Seed Setting} Percentage (SSP)

Anthers of five mature florets from a panicle that had initiated a heading were collected for three consecutive days, and they were subjected to microscopic examination. Pollen grains were stained with $1 \%$ potassium iodide solution $\left(\mathrm{I}_{2}-\mathrm{KI}\right)$, observed under a microscope, and the numbers of fertile and sterile pollen grains were counted in three fields of view for the same slide. Round and deeply stained pollens were considered fertile and pollen fertility percentage (PFP) was calculated from the number of fertile grains divided by the total number of grains. After sampling was performed, the flowered spikelets from the panicle were removed, after which the panicle was bagged. Two weeks later, the SSP was determined.

\section{Results}

Photo-Thermo-Response Characteristics of H93S during the Fertility-Sensitive Period and its CSIT

During the fertility-sensitive period, H93S and the control (PA64S) were subjected to various combinations of light and temperature. Afterward, the fertility rates after the treatment were calculated, the results of which are shown in Table 1 and Supplementary Fig. S2. At $23.0^{\circ} \mathrm{C}$, the PFPs of H93S were $0 \%$ under a $14.5 \mathrm{~h}$ or $13.5 \mathrm{~h}$ photoperiod and $8.21 \%$ under a $12.5 \mathrm{~h}$ photoperiod with a SSP of $2.54 \%$, which increased to $50.51 \%$ with an 11.5 $\mathrm{h}$ photoperiod with a corresponding SSP of $17.84 \%$. At $22.5^{\circ} \mathrm{C}$, the PFP and SSP of H93S under a $13.5 \mathrm{~h}$ photoperiod were significantly higher than those under a 14.5 $\mathrm{h}$ photoperiod. The $11.5 \mathrm{~h}$ and $12.5 \mathrm{~h}$ photoperiod treatments were not tested because under these conditions, two-line male sterile rice generally shows normal fertility, rendering the treatment unnecessary (Chen et al. 2011). At $24^{\circ} \mathrm{C}$, the fertility of $\mathrm{H} 93 \mathrm{~S}$ slightly fluctuated only under short-photoperiod conditions $(11.5 \mathrm{~h})$, with an average PFP of less than $0.01 \%$. At $28^{\circ} \mathrm{C}, \mathrm{H} 93 \mathrm{~S}$ and the control were $100 \%$ sterile regardless of the photoperiod. Thus, the CSIT of $\mathrm{H} 93 \mathrm{~S}$ is $23.0^{\circ} \mathrm{C}$ under $13.5 \mathrm{~h}$ to $14.5 \mathrm{~h}$ photoperiods, which is in agreement with the results of the official report when H93S was released (Huang et al. 2018).

Clearly, at the same temperature in the fertilityrestoration temperature range, the fertility of H93S increased as the photoperiod decreased, suggesting that H93S is a photo-thermo-sensitive interaction type. The control, PA64S, also exhibited similar photo-thermoresponse characteristics associated with fertility transition, and the CSIT was $24.0^{\circ} \mathrm{C}$ under a $13.5 \mathrm{~h}$ photoperiod.

\section{Effects of Cumulative ELT}

Both H93S and PA64S were subjected to various ELT treatments (for $7 \mathrm{~d}$ under a $13.5 \mathrm{~h}$ photoperiod; Table 2 , 
Supplementary Tables S1 and S2) during the fertilitysensitive period to simulate ALT for which the DAT was higher than the CSIT, but the temperature during the night was lower than the CSIT. The results of the fertility assessment are shown in Table 3. Among the 12 temperature treatment combinations, seven presented DATs higher than the CSIT for H93S $\left(\mathrm{T}_{\mathrm{c}}=23.0^{\circ} \mathrm{C}\right.$ under a $13.5 \mathrm{~h}$ photoperiod), and five treatments presented DATs lower than the CSIT. For example, when $t_{1}=11 \mathrm{~h}$ and $t_{2}=7 \mathrm{~h}$, two values of ELT $\left(\mathrm{T}_{\Delta}\right)$ were used during the night $\left(\mathrm{T}_{\Delta 1}=2.5^{\circ} \mathrm{C}, \mathrm{T}_{\Delta 2}=2.0^{\circ} \mathrm{C}\right)$, and at $\mathrm{T}_{\Delta 1}$, the plants were treated with $20.5^{\circ} \mathrm{C}\left(\mathrm{T}_{\mathrm{c}}-\mathrm{T}_{\Delta 1}\right)$, which is $2.5^{\circ} \mathrm{C}$ lower than the CSIT during the nighttime, corresponding to an $\Sigma \mathrm{T}_{\Delta 1}=\left(\mathrm{T}_{\Delta 1}\left(2.5^{\circ} \mathrm{C}\right) * \mathrm{t}_{2}(7 \mathrm{~h})^{*} 7 \mathrm{~d}\right) / 24 \mathrm{~h}=$ $5.10^{\circ} \mathrm{C} \cdot \mathrm{d}$ and a DAT of $\left\{\left(6 \mathrm{~h}^{\circ} 25^{\circ} \mathrm{C}\right)+\left(\mathrm{t}_{1}(11 \mathrm{~h}) * 26^{\circ} \mathrm{C}\right)+\right.$ $\left(\mathrm{t}_{2}(7 \mathrm{~h}) *\left(\mathrm{~T}_{\mathrm{c}}\left(23^{\circ} \mathrm{C}\right)-\mathrm{T}_{\Delta 1}\left(2.5^{\circ} \mathrm{C}\right)\right)\right\} / 24 \mathrm{~h}=24.15^{\circ} \mathrm{C}$. Similarly, at $\mathrm{T}_{\Delta 2}$, the treatment corresponded to $\Sigma \mathrm{T}_{\Delta 2}=$ $4.08^{\circ} \mathrm{C} \cdot \mathrm{d}$ and a DAT of $24.29^{\circ} \mathrm{C}$. These results indicated that the DATs of the two temperature treatments were higher than the CSIT of $\mathrm{H} 93 \mathrm{~S}\left(23.0^{\circ} \mathrm{C}\right)$, however, owing to the ELT treatment at night, the fertility of H93S restored, as reflected by PFPs of $3.10 \%$ and $1.53 \%$ and corresponding SSPs of $1.31 \%$ and $1.01 \%$, respectively. In the $\mathrm{T}_{\Delta 1}$ and $\mathrm{T}_{\Delta 2}$ treatments under $t_{1}=9 \mathrm{~h}$ and $t_{2}=9 \mathrm{~h}$, at $t_{1}=7 \mathrm{~h}$ and $t_{2}=11 \mathrm{~h}$, and with respect to $T_{\Delta 2}$ treatment at $t_{1}=5 \mathrm{~h}$ and $t_{2}=13 \mathrm{~h}$, all the DATs were all higher than the CSIT, and H93S showed varying degrees of PFP and SSP. In the remaining five treatments in which the DAT was lower than the CSIT, the PFP and SSP of H93S were higher than those in the aforementioned seven treatments, with the greatest PFP of $42.36 \%$ and the greatest SSP of $10.06 \%$ in the $\mathrm{T}_{\Delta 1}$ treatment at $\mathrm{t}_{1}=1$ $\mathrm{h}$ and $\mathrm{t}_{2}=17 \mathrm{~h}$, respectively.

At the same temperature, because the CSIT of PA64S was $24.0^{\circ} \mathrm{C}$, which was different from that of $\mathrm{H} 93 \mathrm{~S}$ $\left(23.0^{\circ} \mathrm{C}\right.$ ), the corresponding $\mathrm{T}_{\Delta}$ was always $1.0^{\circ} \mathrm{C}$ higher than that of H93S; i.e., $\mathrm{T}_{\Delta 1}^{\prime}=3.5^{\circ} \mathrm{C}$ and $\mathrm{T}^{\prime}{ }_{\Delta 2}=3.0^{\circ} \mathrm{C}$. As shown in Table 3, the DATs of the two treatments at $t_{1}=11 \mathrm{~h}$ and $t_{2}=7 \mathrm{~h}$ were higher than the CSIT of PA64S, leading to fertility restoration, with PFPs of $5.27 \%$ and $5.86 \%$ and SSPs of $0.42 \%$ and $2.62 \%$, respectively. In the other treatments, all the DATs were lower than the CSIT of PA64S, with significantly increased PFP and SSP.

On the basis of the results shown in Table 3, the PFP change trends for H93S and PA64S with the $\Sigma \mathrm{T}_{\Delta}$ were plotted (Fig. 1). The graph indicates that as the $\Sigma \mathrm{T}_{\Delta}$ increased, the PFPs gradually tended to increase, suggesting that the fertility transition of two-line male sterile

Table 3 The PFPs and SSPS of H93S and PA64S after $7 \mathrm{~d}$ of treatment under different $\Sigma \mathrm{T}_{\triangle}$ conditions and a $13.5 \mathrm{~h}$ photoperiod

\begin{tabular}{|c|c|c|c|c|c|c|c|c|c|c|c|c|c|}
\hline $\begin{array}{l}\text { PTGMS } \\
\text { lines }\end{array}$ & $\mathrm{T}_{\Delta}\left({ }^{\circ} \mathrm{C}\right)$ & PFP (\%) & SSP (\%) & PFP (\%) & SSP (\%) & PFP (\%) & SSP (\%) & PFP (\%) & SSP (\%) & PFP (\%) & SSP (\%) & PFP (\%) & SSP (\%) \\
\hline & & \multicolumn{2}{|c|}{$\begin{array}{l}\mathrm{t}_{1}=11 \mathrm{~h}, \mathrm{t}_{2}=7 \mathrm{~h} ; \\
\mathrm{T}_{\mathrm{d}}=24.15^{\circ} \mathrm{C}\end{array}$} & \multicolumn{2}{|c|}{$\begin{array}{l}\mathrm{t}_{1}=9 \mathrm{~h}, \mathrm{t}_{2}=9 \mathrm{~h} ; \\
\mathrm{T}_{\mathrm{d}}=23.69^{\circ} \mathrm{C}\end{array}$} & \multicolumn{2}{|c|}{$\begin{array}{l}\mathrm{t}_{1}=7 \mathrm{~h}, \mathrm{t}_{2}=11 \mathrm{~h} ; \\
\mathrm{T}_{\mathrm{d}}=23.23^{\circ} \mathrm{C}\end{array}$} & \multicolumn{2}{|c|}{$\begin{array}{l}\mathrm{t}_{1}=5 \mathrm{~h}, \mathrm{t}_{2}=13 \mathrm{~h} ; \\
\mathrm{T}_{\mathrm{d}}=22.77^{\circ} \mathrm{C}\end{array}$} & \multicolumn{2}{|c|}{$\begin{array}{l}\mathrm{t}_{1}=3 \mathrm{~h}, \mathrm{t}_{2}=15 \mathrm{~h} ; \\
\mathrm{T}_{\mathrm{d}}=22.31^{\circ} \mathrm{C}\end{array}$} & \multicolumn{2}{|c|}{$\begin{array}{l}\mathrm{t}_{1}=1 \mathrm{~h}, \mathrm{t}_{2}=17 \mathrm{~h} ; \\
\mathrm{T}_{\mathrm{d}}=21.85^{\circ} \mathrm{C}\end{array}$} \\
\hline H93S & $\begin{array}{l}\mathrm{T}_{\mathrm{c}}= \\
23.0^{\circ} \mathrm{C} \\
\mathrm{T}_{\Delta 1}= \\
2.5^{\circ} \mathrm{C}\end{array}$ & $\begin{array}{l}3.10 \pm \\
0.21\end{array}$ & $\begin{array}{l}1.31 \pm \\
0.11\end{array}$ & $\begin{array}{l}5.41 \pm \\
0.60\end{array}$ & $\begin{array}{l}2.05 \pm \\
0.37\end{array}$ & $\begin{array}{l}12.50 \pm \\
2.07\end{array}$ & $\begin{array}{l}3.01 \pm \\
1.07\end{array}$ & $\begin{array}{l}15.96 \pm \\
0.47\end{array}$ & $\begin{array}{l}3.44 \pm \\
0.37\end{array}$ & $\begin{array}{l}36.12 \pm \\
0.28\end{array}$ & $\begin{array}{l}7.84 \pm \\
0.36\end{array}$ & $\begin{array}{l}42.36 \pm \\
0.35\end{array}$ & $\begin{array}{l}10.06 \pm \\
0.42\end{array}$ \\
\hline$\sum T_{\Delta}{ }^{\circ} \mathrm{C} \cdot \mathrm{d}$ & & 5.10 & & 6.56 & & 8.02 & & 9.48 & & 10.94 & & 12.40 & \\
\hline PA64S & $\begin{array}{l}\mathrm{T}_{\mathrm{C}}= \\
24.0^{\circ} \mathrm{C} \\
\mathrm{T}_{\Delta 1}= \\
3.5^{\circ} \mathrm{C}\end{array}$ & $\begin{array}{l}5.27 \pm \\
2.58\end{array}$ & $\begin{array}{l}0.42 \pm \\
0.09\end{array}$ & $\begin{array}{l}7.87 \pm \\
0.06\end{array}$ & $\begin{array}{l}1.17 \pm \\
0.91\end{array}$ & $\begin{array}{l}20.06 \pm \\
1.06\end{array}$ & $\begin{array}{l}4.82 \pm \\
0.96\end{array}$ & $\begin{array}{l}36.89 \pm \\
0.45\end{array}$ & $\begin{array}{l}7.62 \pm \\
0.61\end{array}$ & $\begin{array}{l}56.11 \pm \\
0.10\end{array}$ & $\begin{array}{l}16.21 \pm \\
2.50\end{array}$ & $\begin{array}{l}59.60 \pm \\
0.60\end{array}$ & $\begin{array}{l}11.76 \pm \\
1.36\end{array}$ \\
\hline \multirow[t]{2}{*}{$\sum T_{\Delta} /{ }^{\circ} \mathrm{C} \cdot \mathrm{d}$} & & 7.15 & & 9.19 & & 11.23 & & 13.27 & & 15.31 & & 17.35 & \\
\hline & & \multicolumn{2}{|c|}{$\begin{array}{l}\mathrm{t}_{1}=11 \mathrm{~h}, \mathrm{t}_{2}=7 \mathrm{~h} ; \\
\mathrm{T}_{\mathrm{d}}=24.29^{\circ} \mathrm{C}\end{array}$} & \multicolumn{2}{|c|}{$\begin{array}{l}\mathrm{t}_{1}=9 \mathrm{~h}, \mathrm{t}_{2}=9 \mathrm{~h} ; \\
\mathrm{T}_{\mathrm{d}}=23.88^{\circ} \mathrm{C}\end{array}$} & \multicolumn{2}{|c|}{$\begin{array}{l}\mathrm{t}_{1}=7 \mathrm{~h}, \mathrm{t}_{2}=11 \mathrm{~h} ; \\
\mathrm{T}_{\mathrm{d}}=23.46^{\circ} \mathrm{C}\end{array}$} & \multicolumn{2}{|c|}{$\begin{array}{l}\mathrm{t}_{1}=5 \mathrm{~h}, \mathrm{t}_{2}=13 \mathrm{~h} ; \\
\mathrm{T}_{\mathrm{d}}=23.04^{\circ} \mathrm{C}\end{array}$} & \multicolumn{2}{|c|}{$\begin{array}{l}\mathrm{t}_{1}=3 \mathrm{~h}, \mathrm{t}_{2}=15 \mathrm{~h} ; \\
\mathrm{T}_{\mathrm{d}}=22.63^{\circ} \mathrm{C}\end{array}$} & \multicolumn{2}{|c|}{$\begin{array}{l}\mathrm{t}_{1}=1 \mathrm{~h}, \mathrm{t}_{2}=17 \mathrm{~h} \\
\mathrm{~T}_{\mathrm{d}}=22.21^{\circ} \mathrm{C}\end{array}$} \\
\hline H93S & $\begin{array}{l}\mathrm{T}_{\mathrm{C}}= \\
23.0^{\circ} \mathrm{C} \\
\mathrm{T}_{\Delta 2=} \\
2.0^{\circ} \mathrm{C}\end{array}$ & $\begin{array}{l}1.53 \pm \\
0.45\end{array}$ & $\begin{array}{l}1.01 \pm \\
0.26\end{array}$ & $\begin{array}{l}2.03 \pm \\
0.27\end{array}$ & $\begin{array}{l}0.85 \pm \\
0.19\end{array}$ & $\begin{array}{l}7.40 \pm \\
0.88\end{array}$ & $\begin{array}{l}1.91 \pm \\
0.39\end{array}$ & $\begin{array}{l}8.66 \pm \\
1.71\end{array}$ & $\begin{array}{l}2.55 \pm \\
0.50\end{array}$ & $\begin{array}{l}14.59 \pm \\
0.13\end{array}$ & $\begin{array}{l}5.68 \pm \\
1.98\end{array}$ & $\begin{array}{l}20.63 \pm \\
0.54\end{array}$ & $\begin{array}{l}5.03 \pm \\
1.11\end{array}$ \\
\hline$\sum \mathrm{T}_{\Delta} /{ }^{\circ} \mathrm{C} \cdot \mathrm{d}$ & & 4.08 & & 5.25 & & 6.42 & & 7.58 & & 8.75 & & 9.92 & \\
\hline PA64S & $\begin{array}{l}\mathrm{T}_{\mathrm{C}}= \\
24.0^{\circ} \mathrm{C} \\
\mathrm{T}_{\Delta 2=}= \\
3.0^{\circ} \mathrm{C}\end{array}$ & $\begin{array}{l}5.86 \pm \\
1.18\end{array}$ & $\begin{array}{l}2.62 \pm \\
0.64\end{array}$ & $\begin{array}{l}10.12 \pm \\
1.93\end{array}$ & $\begin{array}{l}3.11 \pm \\
0.84\end{array}$ & $\begin{array}{l}16.25 \pm \\
0.44\end{array}$ & $\begin{array}{l}4.01 \pm \\
0.26\end{array}$ & $\begin{array}{l}18.38 \pm \\
1.52\end{array}$ & $\begin{array}{l}6.59 \pm \\
1.41\end{array}$ & $\begin{array}{l}32.75 \pm \\
2.18\end{array}$ & $\begin{array}{l}8.01 \pm \\
0.45\end{array}$ & $\begin{array}{l}42.33 \pm \\
0.55\end{array}$ & $\begin{array}{l}10.80 \pm \\
0.45\end{array}$ \\
\hline$\sum \mathrm{T}_{\Delta} /{ }^{\circ} \mathrm{C} \cdot \mathrm{d}$ & & 6.13 & & 7.88 & & 9.63 & & 11.38 & & 13.13 & & 14.88 & \\
\hline
\end{tabular}

$\mathrm{T}_{\Delta}$ is the value of the ELT; $\mathrm{T}_{\mathrm{c}}$ is the value of the CSIT; PFP is the pollen fertility percentage; SSP is the self-seed setting percentage; $\Sigma \mathrm{T}_{\Delta}$ is the value of the cumulative ELT, calculated according to the formula $\Sigma T_{\Delta}=\left(T_{\Delta}{ }^{*} t_{2}{ }^{*} 7 \mathrm{~d}\right.$ )/24 $\mathrm{h}$ (for $\mathrm{t}_{2}$, see Table 2); and $\mathrm{T}_{\mathrm{d}}$ is the DAT calculated according to Table 2 via the following formula $T_{d}=\left\{6 h^{*} 25^{\circ} \mathrm{C}+t_{1} * 26^{\circ} \mathrm{C}+t_{2}^{*}\left(T_{c}-T_{\Delta}\right)\right\} / 24 h$. All the data are expressed as the means \pm the standard errors 


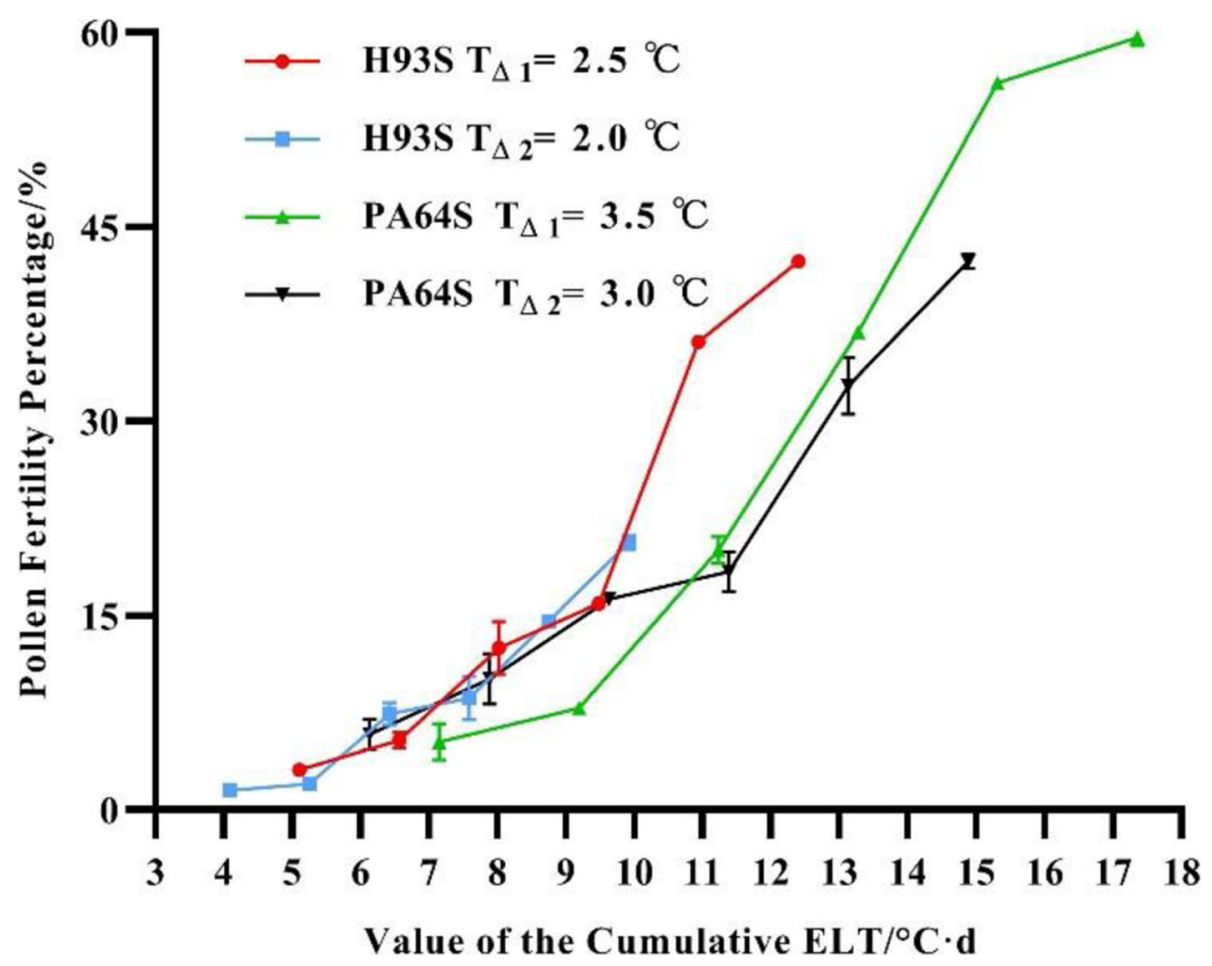

Fig. 1 Pollen fertility percentage of H93S and PA64S after $7 \mathrm{~d}$ of treatment under different $\Sigma T_{\Delta}$ conditions. The actual data for all the $\Sigma T_{\Delta}$ values are shown in Table 3

rice is affected primarily by the cumulative ELT, which supports our hypothesis of the effect of cumulative ELT.

\section{Study of the Number of ELT-Response Days}

The results confirmed that there is an effect of cumulative ELT on the fertility transition of H93S as well as PA64S, which requires a certain number of ELTresponse days or a certain $\Sigma \mathrm{T}_{\Delta}$. Thus, we evaluated the number of ELT-response days (Table 4), and the results showed that at $\mathrm{T}_{\Delta}=0{ }^{\circ} \mathrm{C}$ (control), after $4-7 \mathrm{~d}$ of treatment, H93S and the control were sterile, with a PFP of $0 \%$. At $\mathrm{T}_{\Delta}=1.0^{\circ} \mathrm{C}$, after $7 \mathrm{~d}$ of treatment, the PFPs of
H93S and PA64S were $8.79 \%$ and $5.63 \%$, respectively. At $\mathrm{T}_{\Delta}=1.5^{\circ} \mathrm{C}, 2.0^{\circ} \mathrm{C}$, or $2.5^{\circ} \mathrm{C}$, the fertility transition initiated on day 6 after treatment for H93S and on day 5 for PA64S. Similarly, at $\mathrm{T}_{\Delta}=3.0^{\circ} \mathrm{C}$, for $\mathrm{H} 93 \mathrm{~S}$, fertility transition occurred on day 5 , with a PFP of $1.25 \%$, which peaked on day 7 at $44.30 \%$, while that of PA64S was $8.68 \%$ on day 5 and peaked at $51.22 \%$ on day 7 . Figure 2 shows that as $\mathrm{T}_{\Delta}$ and the number of treatment days increased, the pollen fertility of H93S and PA64S increased accordingly, even under the same number of treatment days, the fertility also increased along with the increasing $\mathrm{T}_{\Delta}$.

Table 4 PFPs (\%) of H93S and PA64S with different treatment days and different $\mathrm{T}_{\Delta}$ values under a $13.5 \mathrm{~h}$ photoperiod

\begin{tabular}{|c|c|c|c|c|c|c|c|c|c|c|c|c|}
\hline \multirow{2}{*}{$\begin{array}{l}\text { Treatment } \\
\text { days (d) }\end{array}$} & \multicolumn{2}{|c|}{$\mathrm{T}_{\Delta}=3.0^{\circ} \mathrm{C}$} & \multicolumn{2}{|c|}{$\mathrm{T}_{\Delta}=2.5^{\circ} \mathrm{C}$} & \multicolumn{2}{|c|}{$\mathrm{T}_{\Delta}=2.0^{\circ} \mathrm{C}$} & \multicolumn{2}{|c|}{$\mathrm{T}_{\Delta}=1.5^{\circ} \mathrm{C}$} & \multicolumn{2}{|c|}{$\mathrm{T}_{\Delta}=1.0^{\circ} \mathrm{C}$} & \multicolumn{2}{|c|}{$\mathrm{T}_{\Delta}=0^{\circ} \mathrm{C}(\mathrm{CK})$} \\
\hline & $\begin{array}{l}\text { H93S } \\
\mathrm{T}_{d}= \\
20.0^{\circ} \mathrm{C}\end{array}$ & $\begin{array}{l}\text { PA64S } \\
\mathrm{T}_{\mathrm{d}}= \\
21.0^{\circ} \mathrm{C}\end{array}$ & $\begin{array}{l}\mathrm{H} 93 \mathrm{~S} \\
\mathrm{~T}_{\mathrm{d}}= \\
20.5^{\circ} \mathrm{C}\end{array}$ & $\begin{array}{l}\text { PA64S } \\
\mathrm{T}_{\mathrm{d}}= \\
21.5^{\circ} \mathrm{C}\end{array}$ & $\begin{array}{l}\text { H93S } \\
\mathrm{T}_{\mathrm{d}}= \\
21.0^{\circ} \mathrm{C}\end{array}$ & $\begin{array}{l}\text { PA64S } \\
\mathrm{T}_{\mathrm{d}}= \\
22.0^{\circ} \mathrm{C}\end{array}$ & $\begin{array}{l}\text { H93S } \\
\mathrm{T}_{d}= \\
21.5^{\circ} \mathrm{C}\end{array}$ & $\begin{array}{l}\text { PA64S } \\
\mathrm{T}_{d}= \\
22.5^{\circ} \mathrm{C}\end{array}$ & $\begin{array}{l}\text { H93S } \\
\mathrm{T}_{d}= \\
22.0^{\circ} \mathrm{C}\end{array}$ & $\begin{array}{l}\text { PA64S } \\
\mathrm{T}_{\mathrm{d}}= \\
23.0^{\circ} \mathrm{C}\end{array}$ & $\begin{array}{l}\mathrm{H} 93 \mathrm{~S} \\
\mathrm{~T}_{\mathrm{d}}= \\
23.0^{\circ} \mathrm{C}\end{array}$ & $\begin{array}{l}\text { PA64S } \\
T_{d}= \\
24.0^{\circ} \mathrm{C}\end{array}$ \\
\hline 4 & 0 & 0 & 0 & 0 & 0 & 0 & 0 & 0 & 0 & 0 & 0 & 0 \\
\hline 5 & $\begin{array}{l}1.25 \pm \\
0.27\end{array}$ & $\begin{array}{l}8.68 \pm \\
1.05\end{array}$ & 0 & $\begin{array}{l}6.61 \pm \\
1.08\end{array}$ & 0 & $\begin{array}{l}2.81 \pm \\
0.43\end{array}$ & 0 & $\begin{array}{l}1.62 \pm \\
0.40\end{array}$ & 0 & 0 & 0 & 0 \\
\hline 6 & $\begin{array}{l}6.37 \pm \\
0.54\end{array}$ & $\begin{array}{l}17.03 \pm \\
1.62\end{array}$ & $\begin{array}{l}5.80 \pm \\
1.22\end{array}$ & $\begin{array}{l}10.08 \pm \\
1.31\end{array}$ & $\begin{array}{l}4.50 \pm \\
0.46\end{array}$ & $\begin{array}{l}7.54 \pm \\
0.95\end{array}$ & $\begin{array}{l}3.25 \pm \\
0.65\end{array}$ & $\begin{array}{l}4.60 \pm \\
0.88\end{array}$ & 0 & $\begin{array}{l}2.11 \pm \\
0.95\end{array}$ & 0 & 0 \\
\hline 7 & $\begin{array}{l}44.30 \pm \\
0.72\end{array}$ & $\begin{array}{l}51.22 \pm \\
4.46\end{array}$ & $\begin{array}{l}29.24 \pm \\
0.84\end{array}$ & $\begin{array}{l}42.11 \pm \\
2.73\end{array}$ & $\begin{array}{l}24.03 \pm \\
0.60\end{array}$ & $\begin{array}{l}35.11 \pm \\
1.99\end{array}$ & $\begin{array}{l}16.86 \pm \\
1.36\end{array}$ & $\begin{array}{l}25.82 \pm \\
4.20\end{array}$ & $\begin{array}{l}8.79 \pm \\
0.90\end{array}$ & $\begin{array}{l}5.63 \pm \\
2.10\end{array}$ & 0 & 0 \\
\hline
\end{tabular}

$\mathrm{T}_{\Delta}$ is the value of the ELT (see Table 2); $\mathrm{T}_{\mathrm{d}}$ is the value of DAT, and $\mathrm{T}_{d}=\mathrm{T}_{\mathrm{c}}-\mathrm{T}_{\Delta}$. All the data are expressed as the means \pm the standard errors 

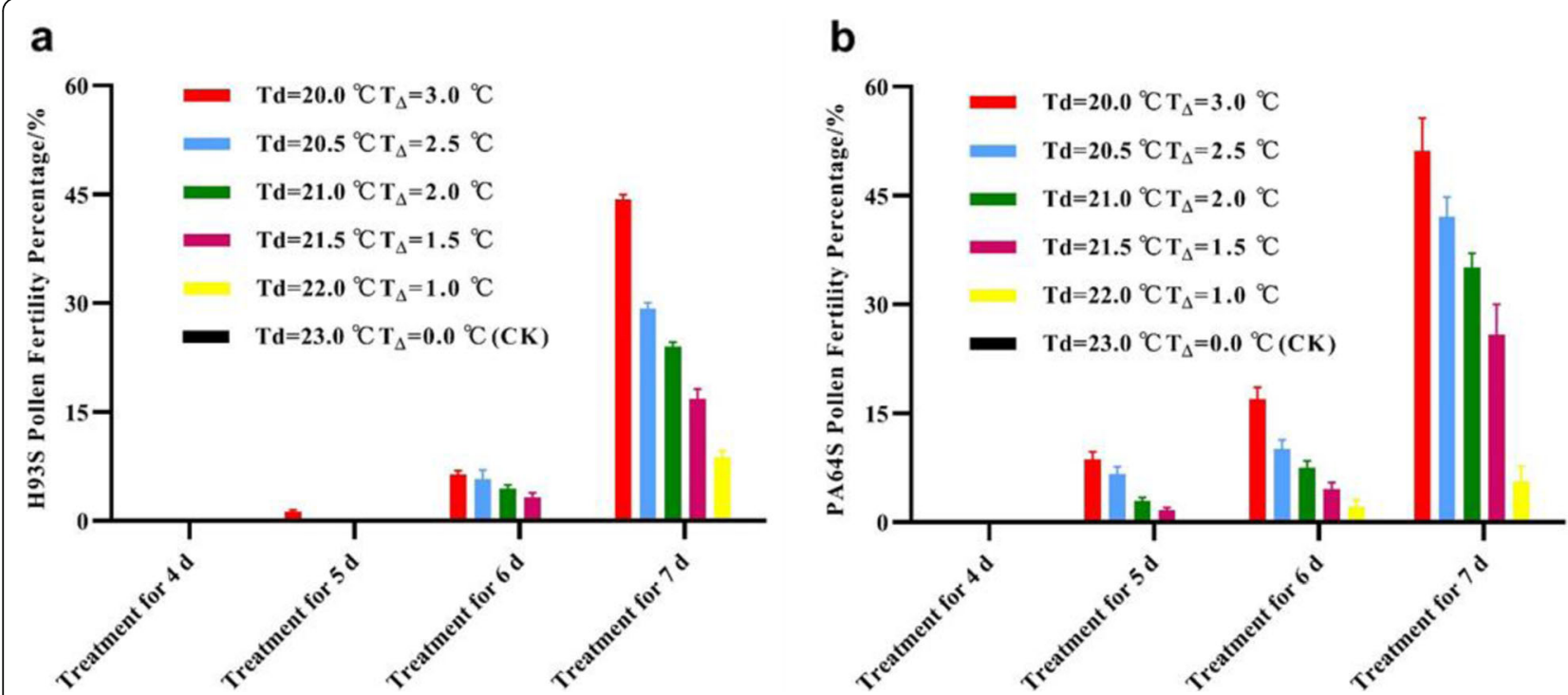

Fig. 2 Pollen fertility of H93S and PA64S with different treatment days and different $\mathrm{T}_{\Delta}$ values with a $13.5 \mathrm{~h}$ photoperiod. a Pollen fertility of H93S. b Pollen fertility of PA64S (Table 4 includes the actual data collected)

\section{Discussion}

Importance of Determining the Precise CSIT

The CSIT of a PTGMS rice line must be determined before the line is released for actual application. In China, the CSIT is determined according to a specific protocol, i.e. NY/T1215-2006 (Sun et al. 2006) or local governmental regulations. The CSIT is a very important indicator for determining the location and period for hybrid seed production or self-propagation (Chen et al. 2011). However, to study the effect of cumulative ELT, this measurement of CSIT is not precise enough, because, according to NY/T1215-2006, the CSIT is determined by only ten treatments $\left(24^{\circ} \mathrm{C}\right.$ and $28^{\circ} \mathrm{C}$ under $11.5 \mathrm{~h}$ and $12.5 \mathrm{~h}$ photoperiods, and $23^{\circ} \mathrm{C}, 24^{\circ} \mathrm{C}$, and $28^{\circ} \mathrm{C}$ under $13.5 \mathrm{~h}$ and $14.5 \mathrm{~h}$ photoperiods), for which the intervals between the temperature settings are too large. For this is the reason, we added four treatments (Table 1) of which the temperatures are close to the original CSIT for H93S and PA64S. In addition, the CSIT of PA64S, which was identified as $\mathrm{T}_{\mathrm{C}}=23.3^{\circ} \mathrm{C}$ when it was released (Luo et al. 1992), drifted upward and once reached to $24.2{ }^{\circ} \mathrm{C}$ (Lei et al. 2014) and was determined to be $24.0^{\circ} \mathrm{C}$ under a $13.5 \mathrm{~h}$ photoperiod in this study.

To determine the effect of cumulative ELT, we estimated the value of ELT very precisely via $\mathrm{T}_{\Delta}=\mathrm{T}-\mathrm{T}_{\mathrm{C}}$. Indeed, if the CSIT is not very precise, the estimates of $\mathrm{T}_{\Delta}$ deviate considerably.

\section{Photo-Thermo Response Characteristics of the Fertility Transition and its Practical Values}

The results of the present study show that H93S is a PTGMS line with a CSIT of $23.0^{\circ} \mathrm{C}$ under $13.5 \mathrm{~h}$ to 14.5 h photoperiods and a CSIT of $24.0^{\circ} \mathrm{C}$ under a $12.5 \mathrm{~h}$ photoperiod, and its photo-thermo-response characteristics are consistent with the interaction model between day length and temperature (He et al. 2007). The CSIT not only changes with generation but also is associated with the photoperiod. As the light duration increases, the CSIT decreases, and vice versa (Tang et al. 2010). The photo-thermo-response characteristics of this type of sterile line are conducive to increased winter generation breeding in Hainan Province, China. During winter, the day length is short, resulting in concurrent increases of the CSIT, which is sufficient to expand the temporal and spatial ranges for self-propagation of twoline male sterile rice. As shown in Table 1, under an $11.5 \mathrm{~h}$ photoperiod and $23.0^{\circ} \mathrm{C}, \mathrm{H} 93 \mathrm{~S}$ showed a higher fertility transition with a PFP of $50.51 \%$; however, very few pollen grains were fertile at $24^{\circ} \mathrm{C}$. This differed from the results of PA64S, where the fertility transition appeared higher at $24^{\circ} \mathrm{C}$ under an $11.5 \mathrm{~h}$ photoperiod with a PFP of $78.31 \%$. Empirically data have shown that, compared with the traditional procedure, the sowing date of PTGMS rice (e.g., H93S) can be postponed by approximately $10 \mathrm{~d}$ (in late November) in some parts of Hainan Province, such as Sanya $\left(109.42^{\circ} \mathrm{N}, 18.39^{\circ} \mathrm{E}\right)$, Lingshui $\left(109.95^{\circ} \mathrm{N}, 18.57^{\circ} \mathrm{E}\right)$, and Ledong $\left(109.05^{\circ} \mathrm{N}, 18.65^{\circ} \mathrm{E}\right)$, such that a normal fertility transition can be achieved at a later time, resulting in a higher reproductive coefficient because the temperature during the sensitive period was slightly higher than the CSIT and the temperature during the subsequent heading and filling stages was more conducive to reproductive growth of rice. 


\section{The Cumulative ELT and Response Days}

In the present study, after exposure to a certain $\Sigma \mathrm{T}_{\Delta}$ for a specific number of days, the fertility of H93S and PA64S could be restored. When the treatment lasted for $7 \mathrm{~d}$, the fertility restoration of the male sterile line was the best with the greatest pollen fertility. The fertility transition of the male sterile line is positively correlated with $\Sigma \mathrm{T}_{\Delta}$. The fertility of the male sterile line increased with the increasing $\Sigma \mathrm{T}_{\Delta}$, which is consistent with the findings of previous studies. Wang et al. (2011b) reported that the fertility of $\mathrm{P} 88 \mathrm{~S}$ at $26.0^{\circ} \mathrm{C}-28.0^{\circ} \mathrm{C}$ is determined by the absolute value of the temperature and the effect of cumulative the temperature. Both Wang et al. (2011a) and Peng et al. (2016) demonstrated that the genetic background and CSIT of the fertility transition in a sterile line are correlated with its sensitivity to sterility at low temperatures. On the basis of our results (Table 4), we can infer that the minimal $\Sigma \mathrm{T}_{\Delta}$ of $\mathrm{H} 93 \mathrm{~S}$ is $15.0^{\circ} \mathrm{C} \cdot \mathrm{d}$ calculated as $\Sigma \mathrm{T}_{\Delta}=\mathrm{T}_{\Delta}\left(3.0^{\circ} \mathrm{C}\right) * 5 \mathrm{~d}$ or $\mathrm{T}_{\Delta}$ $\left(2.5^{\circ} \mathrm{C}\right) * 6 \mathrm{~d}$. However, the results of the 12 ELT treatment combinations (Table 3; Fig. 1) showed that the $\Sigma \mathrm{T}_{\Delta}$ values were all lower than $15.0^{\circ} \mathrm{C} \cdot \mathrm{d}$ ranging from $4.08^{\circ} \mathrm{C} \cdot \mathrm{d}$ to $14.88^{\circ} \mathrm{C} \cdot \mathrm{d}$, thus enabling fertility transitions in both H93S and PA64S. As shown in Table 3, the number of treatment days was $7 \mathrm{~d}$, and fertile pollen grains were observed for values as low as $\Sigma \mathrm{T}_{\Delta}=$ $4.08^{\circ} \mathrm{C} \cdot \mathrm{d}$. Moreover, fertile pollen grains were observed on day 6 with a $\Sigma \mathrm{T}_{\Delta}=15.0^{\circ} \mathrm{C} \cdot \mathrm{d}$ (Table 4 ) suggesting that the fertility transition of $\mathrm{H} 93 \mathrm{~S}$ requires a certain $\Sigma \mathrm{T}_{\Delta}$, as well as a certain number of response days. A lower $\Sigma \mathrm{T}_{\Delta}$ corresponds to a lower number of response days. Based on this study, the fertility transition of the sterile line requires only a certain period of low temperature exposure every day, and other periods can be higher than the CSIT. This also suggests that H93S has a longer duration of low temperature exposure and that if ALT lasts 4-5 d, no fertility transition occurs; thus it is safe and reliable for seed production.

\section{Proposal for the Hypothesis of the Effect of Cumulative ELT}

The main point of this study is that the fertility-sensitive period of PTGMS does not necessarily require the DAT to be lower than CSIT for $4-7 \mathrm{~d}$ to restore fertility. The fertility transition of the sterile line requires only a certain period of low temperature exposure every day, and the temperature of other periods can be higher than the CSIT. In the present study, after the treatment was applied for seven consecutive days for $7 \mathrm{~h}$ at temperatures that were $2.0^{\circ} \mathrm{C}$ higher than the $\mathrm{T}_{\Delta}$ each day (under a $13.5 \mathrm{~h}$ photoperiod, and during other periods, the temperature could be higher than the CSIT), the fertility of H93S was restored, which was also the case for PA64S. This phenomenon supports our hypothesis of the effect of cumulative ELT. Based on this hypothesis, we modified the general fertility transition scheme for the photo-thermo-sensitive male sterile line proposed by Yao et al. (1995), as shown in Fig. 3. Under this new scheme, when the actual (day length) temperature is higher than the fertility transition-critical (day length) temperature, the two-line male sterile rice is sterile. During the fertility-fluctuation period (the period encompassing the stable sterility temperature to the CSIT), the cumulative ELT affects the fertility status, and a certain $\Sigma \mathrm{T}_{\Delta}$ can restore fertility of the two-line male sterile rice. We hypothesize that the effect of the cumulative ELT indicates that the value of the ELT is a key factor affecting the fertility transition within the fertility-fluctuation zone. When the DAT was higher than the CSIT but there was nighttime ALT that reached the lowest ELT, fertility was restored. These findings may explain why hybrid seed production of two-line male sterile rice failed when ALT occurred and supplement the knowledge concerning the fertility transition.

\section{Conclusions}

The main cause of fertility transition is not the DAT being lower than the CSIT but instead is the effect of cumulative ELT. In two-line male sterile rice breeding, the relationship between the DAT of the fertility-sensitive period and the CSIT should not be considered alone. The effects of day length, ALT conditions, and continuous response days should also be considered. As the global climate warms, and the temperature difference between day and night is increasing. The DAT is becoming higher than the CSIT, and ALT together with a night temperature lower than the CSIT frequently occur, which introduces challenges to two-line hybrid seed production because two-line male sterile rice can transition to fertile during the fertility-sensitive period (which is usually from stage IV to stage VI of panicle differentiation), resulting self-pollination. The results showed that fertility transition is not only related to the relationship between the DAT and CSIT but also to the effect of the cumulative ELT. Additionally, a long duration of lowtemperature exposure plays an important role in the fertility transition. The effect of cumulative ELT serves as another scientific and rigorous factor for breeding and hybrid seed production and effectively changes in response to fluctuating global climatic conditions, reducing the risk and expanding the purity and yield of rice. The present study provides new insight into the fertility transition and breeding of two-line male sterile rice.

\section{Abbreviations}

PTGMS: Photo-thermo-sensitive genic male sterile; ALT: Abnormally lowtemperature; DAT: Daily average temperature; CSIT: Critical sterility-inducing temperature; H93S: Hang93S; ELT: Effective low temperature;

PGMS: Photoperiod-sensitive genic male sterile; $\Sigma T_{\Delta}$ : The cumulative ELT; 


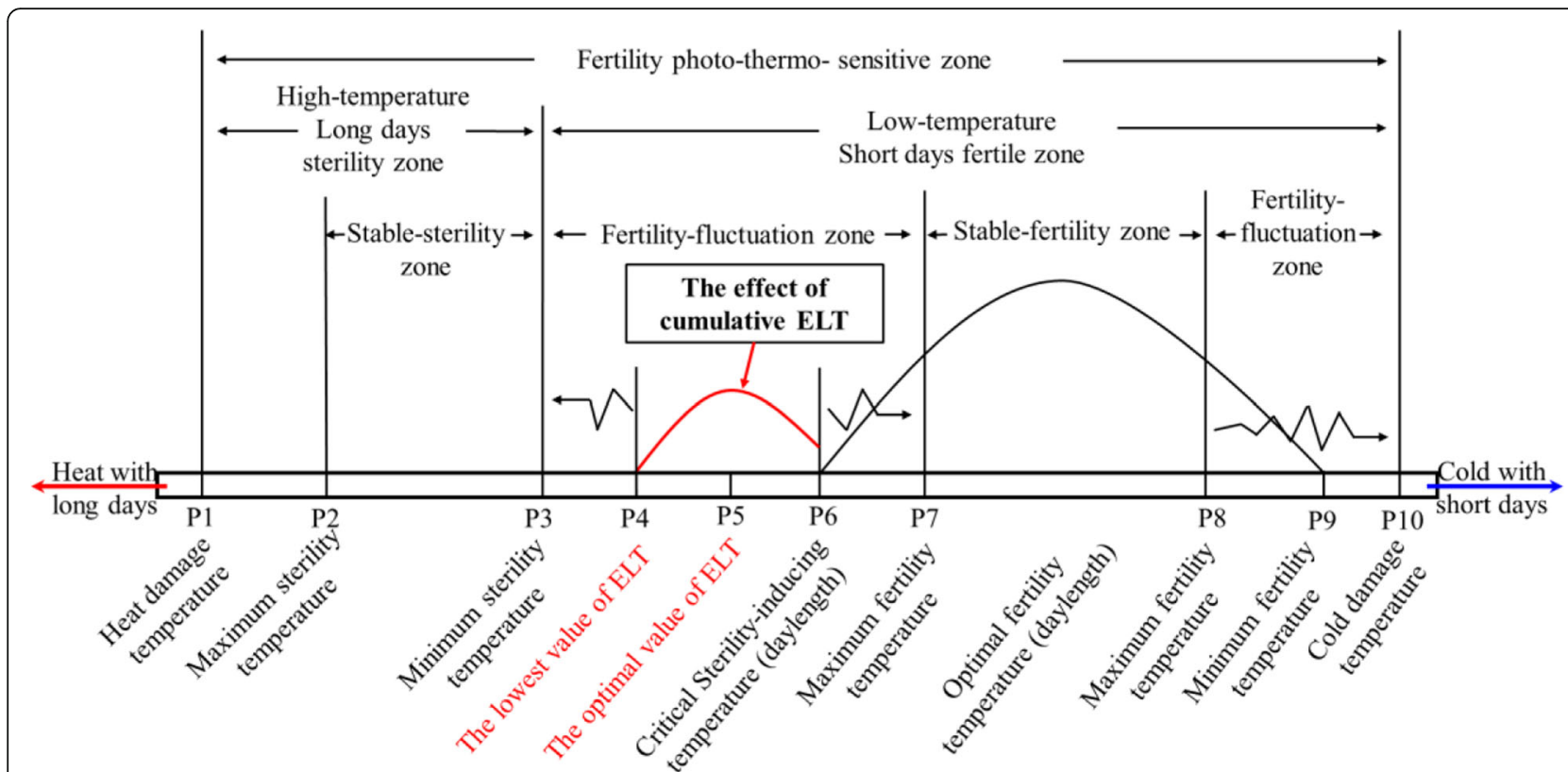

Fig. 3 General scheme of the fertility transition for two-line male sterile rice. The position of red-colored section (from P4 to P6) was modified (added) according to Yao et al. (1995). The horizontal bars represent temperature and day length. The zig-zag lines and the red arrow indicate that the interval lengths between P4 and P3, P6 and P7, P8 and P9, and P4 and P6, respectively, fluctuate due to the changes of photo-thermoconditions, which constitute the "sterility-fluctuation zone". P6 indicates the CSIT (daylength). The transition from P6 to P9 corresponds the stablefertility zone under optimal photo-thermo-conditions while the transition from P3 to P2 corresponds to the stable-sterility zone due to high temperatures and long days. The transition from P9 to P10, or from P2 to P1 is not recommended for self-pollination (propagation) or hybrid seed production because of the extremely low or high temperature, respectively. The transition from P4 to P6, which was not reported by Yao et al. (1995), is the zone of the effect of cumulative ELT which may explain the fertility restoration observed in two-line male sterile rice under ALT (The DAT of the ALT is higher than the CSIT of two-line male sterile rice, but the nighttime temperature is lower than the CSIT)

$T_{\Delta}$ : The value of the ELT; PA64S: PeiAi64S; $T_{c}$ : The value of CSIT; $T_{d}$ : The value of DAT; T: Actual treatment temperature; $\mathrm{I}_{2}$-KI: $1 \%$ Potassium iodide solution; PFP: Pollen fertility percentage; SSP: Self-seed setting percentage;

$\mathrm{t}_{1}$ : Treatment time at $26.0^{\circ} \mathrm{C} ; \mathrm{t}_{2}$ : Treatment time at the temperature of $\mathrm{T}_{c^{-}} \mathrm{T}_{\Delta}$

\section{Supplementary Information}

The online version contains supplementary material available at https://doi. org/10.1186/s12284-021-00514-8.

Additional file $\mathbf{1}$ Fig. S1. Images of the facility used to apply the treatments described in the text. $\mathbf{a}$ and $\mathbf{b}$ Plants growing in precise constant temperature cold water baths for the constant temperature treatments listed in Table 3 and Table 4 with a $13.5 \mathrm{~h}$ photoperiod; c At the end of the treatment, tillers whose distance between the ligule of the flag leaf and that of the next leaf was approximately $1.0 \mathrm{~cm}$ were marked, and the plants were moved back to the field. $\mathbf{d}$ and $\mathbf{e}$ Plants were treated in artificial climate chambers for determining the CSIT. Table 1, Table 2, Table S1 Table S2 and Table S3 include the treatment settings. $\mathbf{f}$ and $\mathbf{g}$ Plants were treated in a large scale smart greenhouse for the study the effect of cumulative ELT by simulating ALT conditions. $\mathbf{h}$ The plants were ready to be transplanted back to the field after the treatments were applied. All the plants under treatment were during their fertility-sensitive period (at the young panicle differentiation IV to VI stage). Fig. S2. Pollen and anther morphology of fertility restoration and abortion of $\mathrm{H} 93 \mathrm{~S}$ and the control PA64S. The images show the a) Normal pollen and $\mathbf{b}$ ) anther morphology of the fertility restoration of H93S (12.5 h, $23.0^{\circ} \mathrm{C}$ ). c) Aborted pollen and d) anther morphology of sterile H93S $\left(11.5 \mathrm{~h}, 24.0^{\circ} \mathrm{C}\right)$. e) Normal pollen and $\left.\mathbf{f}\right)$ anther morphology of fertile PA64S $\left(11.5 \mathrm{~h}, 23.0^{\circ} \mathrm{C}\right)$. $\left.\mathbf{g}\right)$ Aborted pollen and $\mathbf{h}$ ) anther morphology of sterile PA64S $\left(14.5 \mathrm{~h}, 23.0^{\circ} \mathrm{C}\right)$. Scale bars are $100 \mathrm{\mu m}(\mathbf{a}, \mathbf{c}, \mathbf{e}, \mathbf{g})$ and $1 \mathrm{~mm}$ (b, d, f, h)Table S1. Light-temperature conditions during the day at
$\mathrm{T}_{\Delta 1}=2.5^{\circ} \mathrm{C}$. Table S2. Light-temperature conditions during the day at $\mathrm{T}_{\Delta 2}=2.0^{\circ} \mathrm{C}$. Table $\mathbf{S 3}$. Temperature settings for the study of effective treatment days (photoperiod of $13.5 \mathrm{~h}$ ).

\section{Acknowledgements}

The authors thank American Journal Experts for their valuable language editing service.

\section{Authors' Contributions}

LXW and MH conceived and designed the experiments and wrote the paper. LXW, HZR, CC, XL, JFW, WMX and CHH conducted the experiments and analyzed the data. LXW, MH, CC, TG and HW drafted proposals and corrected the manuscript. All the authorshave read and approved the final manuscript.

\section{Funding}

This work was supported by the Guangdong Science and Technology Key R\&D Plan (2018B020202004) and the Guangdong Science and Technology Plan (2017B020201013).

Availability of Data and Materials

Not applicable.

\section{Declarations}

Ethics Approval and Consent to Participate

Not applicable.

\section{Consent for Publication}

Not applicable. 


\section{Competing Interests}

The authors have declared that no competing interest exist.

Received: 21 February 2021 Accepted: 19 July 2021

Published online: 03 August 2021

\section{References}

Arasakesary SJ, Manonmani S, Pushpam R, Robin S (2015) New temperature sensitive genic male sterile lines with better outcrossing ability for production of two-line hybrid rice. Rice Sci 22(1):49-52. https://doi.org/10.101 6/.rsci.2015.05.011

Bai B, Wu J, Sheng WT, Zhou B, Zhou LJ, Zhuang W, Yao DP, Deng QY (2015) Comparative analysis of anther transcriptome profiles of two different rice male sterile lines genotypes under cold stress. Int J Mol Sci 16(12):1139811416. https://doi.org/10.3390/ijms160511398

Barman HN, Sheng Z, Fiaz S, Zhong M, Wu Y, Cai Y, Wang W, Jiao G, Tang S, Wei $X$, Hu P (2019) Generation of a new thermo-sensitive genic male sterile rice line by targeted mutagenesis of TMS5 gene through CRISPR/Cas9 system. BMC Plant Biol 19(1):109. https://doi.org/10.1186/s12870-019-1715-0

Chang ZY, Chen ZF, Wang N, Xie G, Lu JW, Yan W, Zhou JL, Tang XY, Deng XW (2016) Construction of a male sterility system for hybrid rice breeding and seeds production using a nuclear male sterility gene. P Natl Acad Sci USA 113(49):14145-14150. https://doi.org/10.1073/pnas.1613792113

Chen LY, Lei DY, Tang WB, Xiao YH (2011) Thoughts and practice on some problems about research and application of two-line hybrid rice. Rice Sci 18: 79-85. https://doi.org/10.1016/S1672-6308(11)60012-7, 2

Chen LY, Xiao YH (2010) Mechanism of sterility and breeding strategies of photoperiod/thermo-sensitive genic male sterile rice. Chin J Rice Sci 24:103107 (in Chinese with English abstract). https://doi.org/10.3969/j.issn.1001-721 6.2010 .02 .01

Chen QH, Zeng G, Hao M, Jiang HY, Xiao YH (2020) Improvement of rice blast and brown planthopper resistance of PTGMS line C815S in two-line hybrid rice through marker-assisted selection. Molecular Breed 40(2). https://doi. org/10.1007/s11032-020-1098-9

DeGuzman, C, Oard J (2019) Genetics and breeding system for cytoplasmic and genetic male sterility in rice. In. IntechOpen, p5. https://doi.org/10.5772/ intechopen.85191

Ding JH, Lu Q, Ouyang YD, Mao HL, Zhang PB, Yao JL, Xu CG, Li XH, Xiao JH, Zhang QF (2012) A long noncoding RNA regulates photoperiod-sensitive male sterility, an essential component of hybrid rice. P Natl Acad Sci USA 109(7):2654-2659. https://doi.org/10.1073/pnas.1121374109

He Q, Chen LY, Deng HF, Tang WB, Xiao YH, Yuan LP (2007) Fertility photothermo characteristics in PTGMS rice C815S and its homologous plant lines. Acta Agron Sin 33:262-268 (in Chinese with English abstract)

Hu J, Chen XJ, Zhang HY, Ding Y (2015) Genome-wide analysis of DNA methylation in photoperiod- and thermo-sensitive male sterile rice Peiai 645 . Bmc Genomics 16. https://doi.org/10.1186/S12864-015-1317-7

Huang M, Chen C, Zhang XG, Wang H, Guo T, Liu YZ, Xiao WM, Zhao L, Zou YJ, Chen ZC (2018) Dual-low breeding and application of two-line rice 'Peiai 64S' after space flight. J S China Agric Univ 39:34-39 (in Chinese with English abstract). https://doi.org/10.7671/j.issn.1001-411X.2018.02.006

Lei DY, Chen LY (2015) Analysis and thinking of meteorological safety for twoline hybrid rice seeds production in Yancheng, Jiangsu. Hybrid Rice 30:18-20 (in Chinese with English abstract. https://doi.org/10.16267/j.cnki.1005-3956.2 01506006

Lei DY, Tang WB, Xie ZJ, Liu H, Chen LY (2014) Solutions to insecurity problems in seeds production of two-line hybrid rice. Agric Sci Technol 15:11601166,1187. https://doi.org/10.16175/j.cnki.1009-4229.2014.07.025

Peng HF, Chen XH, Ge YY, Wan BH (2016) A comparative study on the low temperature tolerability of different photo-thermo sensitive genic male sterile lines in rice. J South Chin Agric Univ 37:14-19. https://doi.org/10.7671/ j.issn.1001-411X.2016.01.003

Shi MS (1985) The discovery and study of the photosensitive recessive malesterile rice (Oryza sativa L. subsp. japonica). Sci Agric Sin 18:44-48 (in Chinese with English abstract)

Sun ZX, Yu YH, Chen N, Si MH, Shi YF, Wei XH, Hu GC, Xu L (2006) Fertility evaluation protocol of environmental sensitive genic male sterile (EGMS) line of rice iN. Edited by MOA China, NY/T 1215-2006: 8P; A4

Tang WB, Xiao YH, Wang JL, Chen LY (2010) A foundation seeds production method to ensure seed purity of rice ptgms lines by fertility identification of plant lines. Hybrid Rice:25-27+33 (in Chinese with English abstract). https:// doi.org/10.16267/j.cnki.1005-3956.2010.05.010

Virmani SS, Aquino RC, Khush GS (1982) Heterosis breeding in rice, Oryza sativa L. Theor Appl Genet 63(4):373-380. https://doi.org/10.1007/BF00303911

Wang HY, Deng XW (2018) Development of the "third-generation" hybrid rice in China. Genomics Proteomics Bioinformatics 16(6):393-396. https://doi.org/1 0.1016/j.gpb.2018.12.001

Wang W, Liu ZW, Guo ZB, Song GY, Cheng Q, Jiang DM, Zhu YG, Yang DC (2011a) Comparative transcriptomes profiling of photoperiod-sensitive male sterile rice Nongken 585 during the male sterility transition between shortday and long-day. BMC Genomics 12:1-10. https://doi.org/10.1186/1471-21 64-12-462, 1

Wang ZW, Ji DX, Zhang Q, Hua ZT (2011 b) Construction of accumulated temperature effect model for fertility alteration of two-line sterile lines P88S. J Anhui Agri Sci 39(in Chinese with English abstract):17837-17838. https:// doi.org/10.13989/j.cnki.0517-6611.2011.29.176

Wu YZ, Fox TW, Trimnell MR, Wang LJ, Xu RJ, Cigan AM, Huffman GA, Garnaat CW, Hershey H, Albertsen MC (2016) Development of a novel recessive genetic male sterility system for hybrid seeds production in maize and other cross-pollinating crops. Plant Biotechnol J 14(3):1046-1054. https://doi.org/1 $0.1111 / \mathrm{pbi} .12477$

Xu ML, Wu HX, Chen LB, Tang JC, Li WX, Jiang WM, Liang MZ (2002) Studies on identifying the critical sterility-inducing temperature of PTGMS lines in rice with temperature controlled cold water bed. Hybrid Rice:53-55 (in Chinese with English abstract). https://doi.org/10.16267/j.cnki.1005-3956.2002.05.025

Yao KM, Chu CS, Yang YX, Sun RL (1995) A preliminary study of the fertility change mechanism of the photoperiod (temperature period) sensitive genic male sterile rice (PSGMR). Acta Agron Sin:187-197 (in Chinese with English abstract).https://doi.org/10.3321/j.issn:0496-3490.1995.02.011

Yuan LP (2014) Development of hybrid rice to ensure food security. Rice Sci 21: 1-2. https://doi.org/10.1016/S1672-6308(13)60167-5, 1.

Yuan LP, Tang C (1999) Retrospect, current status and prospect of hybrid rice. Rice in China 4:3-6

Zhang DB, Luo X, Zhu L (2011) Cytological analysis and genetic control of rice anther development. J Genet Genomics 38(9):379-390. https://doi.org/10.101 6/j.jgg.2011.08.001

Zhou H, Liu QJ, Li J, Jiang DG, Zhou LY, Wu P, Lu S, Li F, Zhu LY, Liu ZL, Chen LT, Liu YG, Zhuang CX (2012) Photoperiod- and thermo-sensitive genic male sterility in rice are caused by a point mutation in a novel noncoding RNA that produces a small RNA. Cell Res 22(4):649-660. https://doi.org/10.1038/ cr.2012.28

Zhou H, Zhou M, Yang YZ, Li J, Zhu LY, Jiang DG, Dong JF, Liu QJ, Gu LF, Zhou $L Y$, Feng MJ, Qin P, Hu XC, Song CL, Shi JF, Song XW, Ni ED, Wu XJ, Deng QY, Liu ZL, Chen MS, Liu YG, Cao XF, Zhuang CX (2014) RNase Z(S1) processes UbL40 mRNAs and controls thermosensitive genic male sterility in rice. Nat Commun 5(1):4884. https://doi.org/10.1038/ncomms5884

\section{Publisher's Note}

Springer Nature remains neutral with regard to jurisdictional claims in published maps and institutional affiliations.

\section{Submit your manuscript to a SpringerOpen ${ }^{\circ}$ journal and benefit from:}

- Convenient online submission

- Rigorous peer review

- Open access: articles freely available online

- High visibility within the field

- Retaining the copyright to your article

Submit your next manuscript at $\boldsymbol{\nabla}$ springeropen.com 